\title{
Effect of Weather Parameters on Population Buildup of Predatory Coccinellids and Spiders Present in Brinjal Crop Ecosystem of Assam
}

\author{
Rudra N. Borkakati* and D. K. Saikia \\ AICRP on Biological Control, AAU, Jorhat Centre \\ Department of Entomology, Assam Agricultural University, Jorhat-785013, India \\ *Corresponding author
}

\section{A B S T R A C T}

Keywords

Weather parameter, Population build up,

Coccinellids,

Spiders, Brinjal

ecosystem

Article Info

Accepted:

04 August 2020

Available Online:

10 September 2020
Field investigation was carried out during rabi seasons of 2017-18 at the farmer's field, Allengmora, Jorhat to study the effect of weather parameters on population buildup of some predators on brinjal ecosystem. Correlation studies revealed a significant positive association of coccinellid predators with maximum temperature $(\mathrm{r}=0.669)$. Moreover, all the parameters were showed a positive association with coccinellids except average relative humidity ( $r=-0.259)$ which showed a negative impact. However, population buildup of spiders influenced by maximum temperature $(r=$ $0.242)$, minimum temperature $(\mathrm{r}=0.106)$ and bright sunshine hours $(0.373)$ positively, but, average relative humidity $(\mathrm{r}=-0.449)$ and total rainfall $(\mathrm{r}=-$ 0.149) showed a non-significant negative impact during the present study of investigation.

\section{Introduction}

Brinjal, Solanum melongena L. is a nutritious and delicious solanaceous vegetable grown all over India. It is often known as "poor man's vegetable" as well as "King of vegetables" due to popularity amongst common people. In regards to production, India produces 12.8 million metric tonnes per annum from an area of 7.30 lakhs hectare (Anon, 2018). Interestingly, different types insect pests along with their natural enemies are present in brinjal crop ecosystem (Borah et al.,2016 and Borkakati et al., 2019a) and conservation of natural enemies can reduces the dependence on harmful pesticides (Borkakati et al., $2019 b)$. Therefore, proper understanding of biocontrol agents is very much essential in brinjal ecosystem. However, weather parameters play an important role for population buildup of natural enemies along with their pests. Saikia et al., 2020 reported that the significant positive correlation of aphid, Aphis gossypii Glover $(\mathrm{r}=0.662)$ and 
leafhopper, Amrasca biguttula biguttula Ishida $(\mathrm{r}=0.560)$ with maximum temperature in brinjal crop ecosystem. Therefore, present study was carried out mainly to focus on the effect of weather parameters on population buildup of predators present in brinjal ecosystem.

\section{Materials and Methods}

Field experiment was carried out during rabi seasons of 2017-18 at the farmer's field, Allengmora, Jorhat under AICRP on Biological Control of Crop Pests and Weeds. The investigation site is situated at $26^{\circ} 756^{\prime}$ latitude and $94^{\circ} 209 \mathrm{E}^{\prime}$ longitude at an altitude of $86.6 \mathrm{~m}$ above mean sea level.For this purpose, a field with $1000 \mathrm{~m}^{2}$ was raised by adopting Bio-intensive IPM module. The data were recorded from five randomly selected plants from 5 spots of $200 \mathrm{~m}^{2}$ area. Since Coccinellids were congregated towards terminal parts of the plant; three leaves were sampled from each of the five randomly selected plants and the number of beetles per leaf were counted. Such observations were recorded at weekly interval. Spiders were trapped by using pitfall trap @ 5 nos. in each spots.

\section{Results and Discussion}

During the period of present investigation, four numbers of predatorwas predominant viz., Coccinellid beetle (Coccinella transversalis and Serangium parcesetosum) and Spider (Oxyopes javanus \& Lycosa pseudoannulata) in the brinjal ecosystem (Table-1).

\section{Coccinellid beetle, Coccinella transversalis \& Serangium parcesetosum}

The activity of Coccinellid beetlewas recorded to fluctuate at various time intervals. Coccinellid predators were observed during the period of investigation from last week of September 2017 with a population ranging from 0.14 to 2.60 adult/plant. However, the peak activity of the coccinellid predator was recorded during second week of November 2017. This might be due to favorable weather conditions and presence of huge number of prey like aphids and leafhopper. The present findings of population buildup of the coccinellids was analogous with the findings of Chandrakumar et al., (2008) to some extent, they reported that the maximum population of coccinellids appeared in the field during first week of December.

Correlation studies (Table-2) revealed a significant positive association of coccinellid predators with maximum temperature $(\mathrm{r}=$ 0.669). Moreover, all the parameters were showed a positive association with coccinellids except average relative humidity $(r=-0.259)$ which showed a negative impact. The present finding was in conformity with Begam et al., (2016); and Borah and Saikia (2017) who reported that maximum temperature had a significant association with population buildup of coccinellid predators. Besides, these, the present findings were also in line of conformity with the findings of Pal and Singh (2012) who reported that the population buildup of coccinellids exerted significant positive impact on the aphid population.

\section{Spider, Oxyopes javanus \& Lycosa pseudoannulata}

The incidence of spiders were observed on brinjal crop from first week of October 2017 and remained active up to first week of December 2017 with a fluctuating population ranging from 0.57 to 3.00 spider/plant. Peak population of the spider was recorded during last week of November 2017 with 3.00 spider/ plant. In the present investigation, moderately high maximum temperature had been found to 
be conductive for population buildup of the spiders. These results were not supported by the findings of Koushik et al., (2014), who recorded the maximum number of spiders during April month.

The correlation study (Table-2) indicated that, maximum temperature $(\mathrm{r}=0.242)$, minimum temperature $(\mathrm{r}=0.106)$ and bright sunshine hours (0.373) showed a non-significant positive effect whereas, average relative humidity $(\mathrm{r}=-0.449)$ and total rainfall $(\mathrm{r}=$ 0.149) showed a non-significant negative impact on the population buildup of spiders in the brinjal ecosystem during the present study of investigation. These findings were fairly in line of conformity with that of Koushik et al., (2014), who established a non-significant positive correlation with maximum and minimum temperature and average rainfall on spider incidence. Mutkule et al., 2017 observed that the fruit borer damage correlated with weather parameters indicated highly significant positive correlation with maximum temperature, mean temperature and bright sunshine hours.

Table.1 Population build-up of predators of brinjal pests

\begin{tabular}{|c|c|c|c|c|c|c|}
\hline \multirow{2}{*}{$\begin{array}{c}\text { Period of } \\
\text { observation }\end{array}$} & \multicolumn{3}{|c|}{ Coccinellids per plant\# } & \multicolumn{3}{|c|}{ Spider per spot* } \\
\hline & $\begin{array}{c}\text { Coccinella } \\
\text { transversalis }\end{array}$ & $\begin{array}{c}\text { Serangium } \\
\text { parcesetosum }\end{array}$ & Total & $\begin{array}{l}\text { Oxyopes } \\
\text { javanus }\end{array}$ & $\begin{array}{l}\text { Lycosa } \\
\text { pseudoannulata }\end{array}$ & Total \\
\hline 28.09.17-04.10.17 & 0 & 0.91 & 0.91 & 0 & 0 & 0 \\
\hline 05.10.17-11.10.17 & 0.11 & 1.77 & 1.88 & 0 & 0.57 & 0.57 \\
\hline 12.10.17-18.10.17 & 1.78 & 0.73 & 2.51 & 0.15 & 0.99 & 1.14 \\
\hline 19.10.17-25.10.17 & 1.5 & 0.21 & 1.71 & 0.5 & 0.5 & 1 \\
\hline 26.10.17-01.11.17 & 0.5 & 0.55 & 1.05 & 0.8 & 0.34 & 1.14 \\
\hline 02.10.17-08.11.17 & 1.13 & 1.18 & 2.31 & 0.7 & 1.01 & 1.71 \\
\hline 09.11.17-15.11.17 & 2.3 & 0.3 & 2.60 & 1.5 & 1.36 & 2.86 \\
\hline 16.11.17-22.11.17 & 1.9 & 0.04 & 1.94 & 1.7 & 1.3 & 3 \\
\hline 23.11.17-29.11.17 & 1 & 0.11 & 1.11 & 1.2 & 0.23 & 1.43 \\
\hline 30.11.17-06.12.17 & 0 & 0.54 & 0.54 & 0 & 0.71 & 0.71 \\
\hline 07.12.17-13.12.17 & 0.5 & 0.67 & 1.17 & 0 & 0 & 0 \\
\hline 14.12.17-20.12.17 & 0.7 & 0.1 & 0.80 & 0 & 0 & 0 \\
\hline 21.12.17-27.12.17 & 0.1 & 0.24 & 0.34 & 0 & 0 & 0 \\
\hline 28.12.17-04.01.18 & 0.13 & 0.01 & 0.14 & 0 & 0 & 0 \\
\hline
\end{tabular}

\#Mean of 5 randomly selected plants of 5 spot/ *\#Mean of 5 randomly installed spot of 5 spot

Table.2 Correlation studies of predators of brinjal pests with the weather parameters

\begin{tabular}{|l|c|c|c|c|c|}
\hline \multicolumn{1}{|c|}{ Insect Pests } & $\begin{array}{c}\text { Maximum } \\
\text { temperature } \\
\left.\mathbf{(}^{\mathbf{0}} \mathbf{C}\right)\end{array}$ & $\begin{array}{c}\text { Minimum } \\
\text { temperature } \\
\left.\mathbf{(}^{\mathbf{0}} \mathbf{C}\right)\end{array}$ & $\begin{array}{c}\text { Average } \\
\text { Relative } \\
\text { Humidity } \mathbf{( \% )}\end{array}$ & $\begin{array}{c}\text { Total } \\
\text { Rainfall } \\
(\mathbf{m m})\end{array}$ & $\begin{array}{c}\text { BSSH } \\
(\mathbf{h r})\end{array}$ \\
\hline Coccinellids per plant & $0.669^{*}$ & 0.524 & -0.259 & 0.129 & 0.241 \\
\hline Spider per spot & 0.242 & 0.106 & -0.449 & -0.149 & 0.373 \\
\hline
\end{tabular}

* Correlation is significant at 0.05 level 
It is concluded, from the present investigation a significant positive association of coccinellid predators with maximum temperature observed. On the other hand, maximum temperature, minimum temperature and bright sunshine hours showed a positive correlation with spiders. Therefore, the influence of weather parameters cannot be ignored for maintaining the natural enemies in brinjal ecosystem.

\section{Acknowledgement}

The authors are grateful to the Director of NBAIR, Bangaluru for the necessary funding for the experiment. The authors are also indebted to the Director of Research (Agri), Assam Agricultural University, Jorhat-785 013 for their help and suggestion during the course of the investigation.

\section{References}

Anonymous. 2018. Horticultural statistics at a glance 2018. Horticulture Statistics Division, Ministry of Agriculture and Farmers Welfare, Government of India. $10 \mathrm{pp}$.

Begam, N., Saikia, D.K., Borkakati, R. N. 2016. Seasonal incidence of major insect-pests and their natural enemies of Bhut Jolokia. Ann Pl Protec Sci, 24(2): 259-264.

Borah, N., Saikia, D.K., Borkakati, R. N. 2016. Field efficacy of certain insecticides and biopesticides against the major pests of Brinjal and their effect on natural enemies. Pestology, XL(7): 29-33.

Borah, N. and D. K. Saikia (2017). Seasonal incidence of major insect pests of brinjal and their natural enemies. Indian J. Entomol, 79(4): 449-455.

Borkakati, R.N., Saikia, D. K., Buragohain, P. 2018. Natural enemy fauna of agri-horti ecosystem of Assam. Indian $J$.
Entomol,80(3): 658-661.

Borkakati, R. N., Venkatesh, M.R., Saikia, D. K. 2019a. Insect pests of Brinjal and their natural enemies. J Entomol Zool Stud, 7(1): 932-937.

Borkakati, R.N., Saikia, D.K., Venkatesh, M.R. 2019b. Habitat manipulation for managing insect pests of brinjal.Indian J. Entomol, 81(4):717-720.

Chandrakumar, H. L., Chakravarthy, A. K. and Putta Raju, T. B. 2008. Seasonal occurrence of major insect pests and their natural enemies on brinjal. Current Biotica,2(1): 6669.

Koushik, N. R., Manjunatha, M., Shivanna, B. K. and Latha, M. 2014. Seasonal incidence of major insect pests and their natural enemies on brinjal in Shimoga, Karnataka. J. Ecofriendly Agriculture, 9(1): 53-56.

Mutkule, D.S., Patel, Z.P., Ghetiya, L.V., Singh, S. and Mote, B. M. 2017. Effect of weather parameters on seasonal abundance of brinjal shoot and fruit borer in south Gujarat. Journal of Agrometeorology 19 (2):178-179

Pal, M. and Singh, R.2012. Seasonal history of cabbage aphid, Brevicoryne brassicae (L.). J. Aphidol. 25: 69-74.

Saikia. D. K., R. N. Borkakati, M. R. Venkatesh and Sinki Barman. 2020. Role of Weather Parameters on Population Build Up of Minor Insect Pests of Brinjal. Int.J.Curr.Microbiol.App.Sci. $\quad$ 9(07): 397. $402 . \quad$ doi: https://doi.org/10.20546/ijcmas.2020.907.044

Shelton, A. M., Gujar, G. T., Chen, M., Rauf, A., Srinivasan, R., Kalia, V., Mittal, A., Kumari, A., Ramesh, K., Borkakati, R., Zhao, J. Z., Endersby, N., Russell, D. A., Wu, Y.D., Uijtewaal, B. 2009. Assessing the susceptibility of cruciferous Lepidoptera to Cry $1 \mathrm{Ba} 2$ and Cry1Ca4 for future transgenic cruciferous vegetables. J Econ Entomol, 102(6): 2217-2223.

\section{How to cite this article:}

Rudra N. Borkakati and Saikia, D. K. 2020. Effect of Weather Parameters on Population Buildup of Predatory Coccinellids and Spiders Present in Brinjal Crop Ecosystem of Assam. Int.J.Curr.Microbiol.App.Sci. 9(09): 114-117. doi: https://doi.org/10.20546/ijcmas.2020.909.014 